Near final version of: A M Williams and G Shaw (2011), 'Internationalization and innovation in tourism', Annals of Tourism Research

38(1): $27-51$

\title{
INTERNATIONALIZATION AND INNOVATION IN TOURISM
}

\author{
Allan Williams \\ University of Surrey \\ and \\ Gareth Shaw \\ University of Exeter
}

\begin{abstract}
Internationalization and innovation are significant themes in tourism research whose inter-relationship has been largely neglected. Starting from the international economics literature, which focuses largely on the multinational enterprise, and on knowledge issues, the relationship can be conceptualised in three ways: internationalization is a form of innovation, successful internationalization requires innovation, and internationalization requires firms to have superior knowledge. Turning from this generic literature to the specificities of tourism, two aspects of the simultaneity of production and consumption critically shape internationalization: the requirement for co-presence, and consumer mobility. However, a firm-focussed approach fails to address the changing international environment of the enterprise, especially the increasing importance of global connectivity in relation to entrepreneurs, labour and tourists.
\end{abstract}

Keywords: Innovation, internationalization, entrepreneurship, labour, tourists

\section{INTRODUCTION}

Internationalization and innovation in tourism are interwoven but, with few exceptions, the respective literatures have remained unengaged with each other. This constitutes a double lacuna. First, although internationalization is recognized as a central feature, and a driving force, that shapes and reshapes tourism (Lanfant, 1995; Johnson \& Vanetti, 2005; Fayed \& Fletcher, 2002), the economic aspects have been weakly theorised (Knowles, Diamantis \& El-Mourhabi, 2001; Bianchi, 2002; Hjalager, 2007). Yet innovation theories can provide insights into the driving forces, nature, and processes of internationalization. Secondly, internationalization is a key dimension of tourism innovation, evident in terms of markets, knowledge transfer and production conditions. This paper explores how the relationships between innovation and internationalization can be conceptualised, thereby contributing to mapping out future tourism research agendas.

Theoretical work on the economic analysis of both innovation and internationalization traditionally has focussed on manufacturing (Coviello \& Munro, 1997), and 
selectively on some service sectors such as retailing (Alexander \& Dawson, 1994; Coe \& Hess, 2005). In contrast, tourism is relatively neglected (see Sinclair \& Stabler, 1997; Shaw \& Williams, 2004). This is rooted in an ideological paradigm that sees manufacturing as the dynamic motor of the economy. Yet there is strong and growing evidence of the internationalization of tourism, whether in terms of production (Go \& Pine, 1995) or consumption (Vellas \& Becherel, 1995). This makes the relative limited theorisation of tourism innovation particularly surprising.

The starting point for this conceptualization is the most developed area of research in the field, the international economics literature on multi-national enterprises. This asserts the central importance of comparative knowledge advantages, especially under conditions of uncertainty. Originating with Hymer (1960), these theories argue that firms which internationalize necessarily have superior knowledge (and hence innovation capacity) than nationally-focussed companies. Caution is needed here. While the term multi-national has become synonymous with large-scale enterprises, it can refer to any enterprise operating across borders. Internationalisation is not - and probably never was - the exclusive preserve of large corporations (Zahra, 2005). There is also a need to consider internationalization and innovation in small and medium sized enterprises (SMEs) (Prashantham, 2008), which are especially important in tourism (Smeral, 1998; Mungall \& Johnson, 2004).

The generic literatures on internationalization and innovation need to be informed by the specificities of tourism. While there are several distinctive features of tourism innovation (Hall \& Williams, 2008, chapter 1), the key issue in internationalization is the simultaneity of production and consumption. This has two main consequences. First, enterprises that provide services directly (rather than through sub-contracting) to tourists in international markets require co-presence: they must have a material local presence, whether in the form of a car rental office or airline staff at an airport. Secondly, tourism is distinctive in that a significant market segment (international tourism), by definition, is mobile beyond the immediate locality. Firms developing their global reach and brand building (Vellas \& Becherel, 1999) may therefore have to undertake direct foreign investments, requiring associated innovations, if they are targeting the provision of tourism services to non-nationals - whether from their own or other countries - in a foreign destination.

Although international economics provides a useful perspective, it fails to address the changing context of the internationalization of innovation, especially in tourism. The distinctiveness of tourism innovation is shaped not only by the inherent mobility of tourism consumers, but also by the more generalised internationalization of mobility, and connectivity. One of the drivers of innovation, especially in terms of accessing knowledge, is global connectivity (NESTA, 2008). In a globalizing world, there is increasing scope for tourism innovation to be shaped not only by the internationalization of capital, managers and entrepreneurs, but also of tourists and labour. Global connectivity assumes particular importance in the context of the emerging understanding of innovation as being co-produced and co-created (Etgar, 2008).

The first part of the paper reviews the classic theorisation of internationalization in economics, and considers the specificities of tourism in this context, while the second part considers tourism innovation in the context of global connectivity. The final 
section sets out an agenda for future research.

\section{INTERNATIONAL ECONOMICS, MNES AND INNOVATION}

Internationalization is 'a major dimension of the ongoing strategy process of most business firms' (Melin, 1992, p101) and necessarily is important in innovation. Although international economics pays relatively little direct attention to innovation other than in relation to technology transfer (Södersten \& Reed, 1994), several sub fields - such as those on Multinational Enterprises (MNEs), trade and factor costs provide useful insights. One important caveat is that this research has largely focussed on large MNEs, while there is growing recognition of the internationalization of small firms, often at an early stage. This is epitomised as being 'born global' (Knight \& Cavusgil, 1996), and is particularly relevant for tourism (Hjalager, 2007, p438). In this section we present three readings of the relationships between internationalization and innovation, drawing selectively on the international economics literature.

First, internationalization can be understood as a form of innovation. Competitive pressures drive innovation, and tourism firms operate in international markets in order to seek competitive advantage, whether in terms of factor costs or market access (Hjalager, 2007). Calof \& Beamish (1995) define internationalization as the process of becoming aware of the importance of international transactions for the future development of the firm, as well as the process of investing in and undertaking business transactions in other countries. This implicitly involves 'the internal dynamics and learning of the firm as it expands internationally' (Coviello \& Munro, 1997, p.363), and learning and knowledge transfer are central to tourism innovation (Shaw and Williams, 2009). In other words, internationalization is necessarily a form of innovation. Whether or not it constitutes discontinuous, as opposed to incremental, innovation (Sundbo, 1997) partly depends on whether this is new to the firm, new to tourism, or new to the economy. Internationalization as innovation has to be understood as dynamic and despite the fact that stage models inherently simplify the complexities of change, Johanson \& Vahlne's (1977) 'stage' model is helpful in this context. This argues that, in the early stages of internationalization, investment focuses on 'psychically close' markets, in terms of culture, language, and business practices. As firms learn through experience, in the later stages they invest in more 'psychically distant' markets. Although the notion of mobile markets in tourism mediates how we understand psychical distance, the stage model is still useful; firms are providing services to tourists in an institutionally different context, and have to develop new supply chains within this framework. This necessarily requires that they innovate in terms of developing new organizational forms and inter-firm relationships at each stage.

There are several ways in which internationalization constitutes innovation in tourism. One of the main axes is how firms innovate in respect of ownership of, and extraction of rent from, their assets, whether in material, brand, or intellectual property terms. This has particular resonance for tourism, where there are diverse and innovative forms of international joint activities, franchising, and sub-contracting (Shaw and Williams, 2004, chapter three). Other areas of innovation include new organizational forms, and changes in the international value chain (for example, shifting from international to local suppliers). Accordingly, and in a Schumpeterian perspective 
(Drejer, 2004), processing, marketing, organization and institutional innovations may be more important than product innovations in internationalization.

A second perspective is that successful internationalization is dependent on innovation, with success being understood in terms of resultant changes in the performance and competitiveness of the firm. An important caveat is that innovation should be seen as a necessary but not a sufficient condition for successful internationalization. Prashantham (2008, pp.1-2) asserts that: "It has been suggested that if international business scholars agree on a "big question" for the field, it ought to concern explanations of the differential performance of internationalizing firms'. In the context of this paper, that can be translated into a question of what determines whether a firm innovates successfully in relation to internationalization. More specifically, do the requirements for successful innovation differ in the international and domestic arenas, perhaps reflecting differential risks and uncertainty? This is explored in terms of resources, external networking and absorption capacity.

In terms of resources, the obvious starting point is the resource -based theory of the firm (Barney, 1991). One variant of this, the knowledge-based theory of the firm (Nonaka \& Takeuchi, 1995; Grant, 1996), argues that knowledge is the most significant determinant of competitiveness because of its complexity and being difficult to imitate. The challenge of internationalizing is that firms need specific types of encultured and embedded knowledge about the host country, for example about health and safety laws relating to travel or catering. This can mitigate against SMEs, although the 'born global' literature emphasises that many small firms expand rapidly via internationalization. In any case, successful innovation as part of an internationalization strategy requires extensive and selective knowledge.

Innovation requires identifying and harvesting knowledge both within and external to the firm, and internalizing the latter (Liesch, Welch, Welch, McGaughhey, Petersen \& Lamb, 2002, p.20). Successful internationalization therefore requires both openness to external sources of knowledge and effective networking (Johanson \& Mattsson 1988). In practice, networking growth is often haphazard, contributing to 'the erratic character' of internationalization (Benito and Welch 1994), and by extension to the successful innovation this requires. In contrast to innovation in domestic markets, tourism internationalization may also require language capital (Dustmann, 1999) and knowledge of local leisure and other practices. Moreover, as Paget, Dianche and Mounet (2010) demonstrate in the case of ski destinations, international operations are becoming increasingly complex, requiring the co-ordination of external agents such as event managers, sports celebrities and facility constructors.

Innovation requires not only harvesting and transferring knowledge, but also an effective absorption capacity (Zahra \& George, 2002). The main components of this in terms of organization, resources, and culture - are largely similar both in the domestic and international spheres. However, internationalization poses particular challenges in terms of openness and the tolerance/encouragement of diversity if knowledge is to be absorbed successfully (English -Lucek, Darrah, \& Saveri, 2002), and translated into innovation.

A third perspective is that internationalization requires firms to have superior 
knowledge compared to those operating only in the domestic sphere. Firms operating in a different country usually require additional resources to overcome heightened imperfections in information (Liesch, Welch, Welch, McGaughhey, Petersen \& Lamb, 2002; Carlson, 1974). In international economics, the writings on industrial organization (originating with Hymer, 1960 and Kindleberger, 1969 amongst others) suggest that MNEs have absolute ownership-specific advantages over host country firms. By implication, therefore, firms require more knowledge to internationalize, while MNEs posses advantages in the host country through having access to different knowledge from another country. Market knowledge is often considered the key area of superior knowledge required of the firm (Prashantham, 2008), as for example with tour operators. This, in turn, has three key aspects: international market selection, entry mode choice and pace of internationalization (Jones \& Coviello, 2005).

The outcome in terms of innovation depends on the model of knowledge transfer, which in turn is related to models of corporate organization and strategies.

Hymer (1960), Kindleberger (1969) and others envisaged a model of verticallyorganised production whereby knowledge creation is concentrated in the home country, and knowledge transfer mechanisms redistribute this to branch establishments located in different host countries. This model is most effective when the corporate strategy focuses on providing existing products or services which are new to the market in the destination (Hansen , Nohria, \& Tierney, 1999). In other words, this is mostly about replication, and imitative innovation - which are particularly important in tourism.

In a contrasting model of international production, firms seek to launch or develop new and differentiated products (a localisation product strategy), or innovate in processes and organizational forms, in the host country, in response to national differences in markets and production conditions. While most such innovations are of course still likely to be incremental rather than radical, there is a greater likelihood of radical innovation here than in the standardization model. However, there are also differences in how firms harvest knowledge, and Morgan (2001) differentiates between 'multinational' and 'global' enterprises in this respect (Table 1). In global enterprises, knowledge creation is no longer seen as concentrated in the home country but dispersed, with firms co-ordinating inter-relationships amongst their different branches because they value multi-directional learning (p122). In other words, globalised firms are committed to effective internal (and external) networking to transfer knowledge to, and accumulate it at, the organizational level, with a view to uplifting the company's overall innovation performance. Such firms are more likely to be committed to localization, combining local and company wide knowledge, than are what Morgan terms multinational firms, which have uni-directional and hierarchical knowledge flows from centre to branches.

This bipolar model, although useful - not least because standardisation versus localisation is crucial in international tourism - is necessarily a simplification. First, even the most centralised model of knowledge distribution requires some form of local adaptation and innovation. Secondly, a firm's model of internalization is not static, but adapts over time, in response to local learning (Welch \& Welch, 1996). For example, initially firms may lack local knowledge and contacts, encouraging reliance on local operators. At a later stage, having acquired nationally specific knowledge in the host country, they can operate independently of the local firms (Liesch \& Knight, 
1999), with hotels for example buying directly from producers rather than intermediaries. Thirdly, in the face of limited market knowledge, innovation has often been organizational, involving new forms of ownership and leasing arrangements, or mergers and acquisitions, which allow multiple formats for the MNE's knowledge to be combined with local knowledge. This is particularly important in some tourism sectors, such as hotels, where management, ownership of the hotel business, and property ownership are combined in complex ways, including various forms of franchising and licensing (Quinn \& Doherty, 2000).

\section{Internationalization, knowledge and tourism}

Although the international economics literature mostly deals with multinationals as a generic category, 'the majority of FDI (Foreign Direct Investment) is industry-specific and we should look for explanations of FDI in the characteristics of those industries' (Södersten \& Reed, 1994, 470). Two distinctive elements of tourism are the simultaneity of production and consumption; and the (non-local) mobility of markets. The broader implications were noted, in the previous section, in terms of the need for a material presence in the host country, and providing services to non-national tourists in those countries. Both issues present challenges in respect of knowledge and risk. All firms require additional knowledge to overcome the higher risks and uncertainty associated with operating abroad. But in tourism there are also mobile consumers who lack local knowledge and face uncertainty when holidaying abroad. For some tourists, this challenge, and heightened risk, is attractive but many tourists value such risks negatively, creating market opportunities for firms - such as tour companies delivering tourism products with (perceived) reduced risks. This also resonates with traditional typologies, such as Cohen's (1972), which distinguish between the desire for the novel as opposed to the familiar. MNEs benefit in this situation from having a known and trusted brand, and from offering standardised products.

Tourism is, however, a composite sector and innovation and internationalization practices vary across its constitutive sub-sectors (Sinclair \& Stabler, 1997; Shaw \& Williams, 2004). There has probably been more research on hotels than any other subsector (Whitla, Walters \& Davies, 2007; Go \& Pine, 1995). One benchmark study of internationalization in hotels is Dunning \& McQueen (1982), drawing on the eclectic theory of the firm, also known as the OLI (Ownership, Location, Internalization) paradigm. This proposes that internationalization offers three types of advantages to hotels: ownership specific advantages compared to host country establishments (e.g. accumulated knowledge reduces entry costs, and branding appeals to international clients); location specific advantages compared to only investing in the home country (e.g. higher rates of growth, and favourable operating conditions); and market internalization (internalizing the ownership advantages within the firm, rather than say licensing these).

In the generic literature on MNEs, the eclectic theory is challenged by the transaction cost approach (Williamson, 1973). This posits that 'MNEs have the choice of market transaction or intrafirm transaction for production and complementary activities (marketing)...... An MNE emerges if it is cheaper for a company to internalize a transaction which is carried out across national borders' (Kleinert, 2004, pp.31-32). This approach considers separate ownership advantages to be redundant, having been subsumed into internalization (Buckley \& Casson, 1985, p.18). However, ownership 
specific costs and returns are the key here, whether in terms of the eclectic theory or subsumed within transaction costs, for it brings us to the question of whether the firm is providing standardised products and processes, as opposed to localised adaptation.

The balance between standardisation and localisation determines the types of innovation required, and has been researched by Whitla, Walters \& Davies (2007), although more in terms of strategies than innovations. Corporate customers tend to deal with hotel chains with global reach, and known products; such chains require innovation to capture economies of scale relating to purchasing, back office services, and guest reservations. The anticipated outcome would be incremental product innovations, but there are also opportunities for radical or discontinuous organizational innovation. Reality is inevitably more complicated than implied by models of standardised versus localised products and services, with most MNEs seeking to balance these. Whitla, Walters \& Davies (2007) found lower than anticipated standardisation of facilities and amenities, but greater than expected uniformity in customer services and quality standards.

The McDonaldisation thesis points to another area of innovation where tension exists between standardisation and localization. Ritzer \& Liska (1998) argue there is strong tourist demand for the McDonaldisation of holidays, because these are predictable, highly efficient (value for money), calculable in terms of cost, and controlled (in terms of risks). Fully inclusive tours epitomise such products: whereas these were initially driven by discontinuous innovations, they now typify repetitive, incremental innovations. Once again this emphasises the dynamic context of internationalization: over time, MNEs may localize (i.e. customize) their standardised products as they learn about the preferences of domestic consumers. Familiarisation may also make international tourists more willing to accept, or even seek, locally adapted product innovations from the MNEs, or adapted and more standardised products from local service providers. In other words, imitative innovations may occur as the products of locally owned firms and MNEs converge or hybridise.

Much of the preceding discussion has been conceptual, which is the main aim of this paper. Probably the most directly relevant empirical work on internationalization and innovation in tourism has been by Spanish economists, especially a study by Jacob \& Groizard (2007) of technology transfer by Balearic hotel chains operating in Latin America. On average, their hotels in Latin America were more innovative than in the Balearic Islands, and were relatively more likely to be process than product innovations. Emphasising the diversity of knowledge systems, Rodriguez (2002: 65) cautions that the Spanish hotel industry 'maintains a strong dose of tacit knowledge" which is an obstacle to any simple replication of its product internationally, and increases the need for local co-operation with suppliers. Similarly, research on the theme park sector (Matusitz, 2010; Véronneau \& Roy, 2009) indicates the complexity of tourism innovation: new rides may be invented in one location and then transferred nationally and internationally, but - as the experience of EuroDisney shows - have to be localised, involving process innovations.

Another important point is that tourism firms are relatively reliant on suppliers (Hjalager 2010), as part of value chains which may be internationalized. Therefore, internationalization does not necessarily follow the model of innovation at one location, with subsequent international diffusion involving varying degrees of 
standardization versus localization. Instead, innovation can be co-produced across international borders. Indeed, as Hjalager (2007), demonstrates, globalization tends to proceed through varying stages, characterised by different forms of internationalization, including outsourcing, transnational ownership, cross-border marketing, collaboration and various forms of knowledge acquisition. Focussing on ownership advantages and localisation versus standardisation is helpful in understanding the specificity of innovation and internationalization in tourism. However, it only takes us part of the way to fulfilling Södersten \& Reed's (1994) dictum of needing to understand the characteristics of particular sectors. There is also a need to understand how tourism firms interact with the changing external environment - especially the flows that constitute a changing set of global connectivities.

\section{GLOBAL CONNECTIVITY AND INNOVATION}

'The more connected a place is, the better able it is to attract global flows; and the greater its absorptive capacity, the greater its ability to 'domesticate' such flows. Consequently, places benefit or lose from globalisation in accordance with their 'internal capacities' (absorptive capacity' and 'connectivity'), as well as their ability to adapt to and manage external changes (NESTA, 2008, p.11).

Firms are recognised as being '... repositories of competences, knowledge, and creativity, as sites of invention, innovation and learning' (Amin \& Cohendet, 2004, p.2), with their external connections being essential in harvesting knowledge. This is usually expressed in terms of formal links to other firms, private and state knowledgecreating and knowledge-transfer bodies, and informal networking, typified by Wenger's (1998) concept of communities of association. One particular expression of this is innovation networks: 'Innovators rarely innovate alone. They are embedded in dense networks and external relationships that propel, generate and limit opportunities for innovation' (Dodgson, Gann \& Salter, 2008, p.128).

Connectivity has long been internationalised, but arguably a qualitative change has occurred as a consequence of two major globalisation trends: the role of the internet in facilitating what Amin (2002) terms distanciated relationships, and the significant increase in many forms of human mobility. Both trends are important in tourism. IT has provided the basis for what Castells (1996, p.468) terms 'pervasive expansion throughout the entire social structure'. Relatively neglected in comparison, but of particular significance in tourism, has been the internationalisation of human mobility, not only of the flows of entrepreneurs and managers, but also of tourism-related labour/discovery migration, and of tourists. These flows, have transformed the external environment of many tourism firms.

\section{Internationalization of entrepreneurial 'resources' and tourism SMEs}

There is widespread anecdotal and case study evidence of the international mobility of tourism entrepreneurs, ranging from the bars and restaurants owned by migrants in many mass tourism resorts, to the role of iconic and often itinerant hoteliers/restauranteurs (Hall \& Williams, 2008, chapter 7). Less evident is their contribution to innovation processes, or why their role in innovation should differ 
from that of national entrepreneurs. In addressing this question, we consider the nature of entrepreneurship, drawing on two main perspectives: resource-based theory and ethnic SMEs.

In his classic work, Schumpeter (1934) stressed that entrepreneurs have the ability to identify and realise opportunities (Penrose, 1959). Entrepreneurship also requires willingness to take risks, and strategic managerial capacity to organize resources and, implicitly, the same applies to successful innovation. One such area of innovation is internationalization where, given uneven knowledge, the anticipated risks are significantly greater than in the domestic sphere. Consequently, additional resources are required to overcome these challenges. Smaller firms have more limited resources than MNEs, but can and do overcome this barrier by effectively marshalling available resources (Zahra, 2005). As Hitt, Bierman, Shimizu \& Kochhar (2001, p.480) argue: '... internationalizing small firms' need to "punch above their weight", as it were, and resourcefully use their limited means to internationalize'. The starting point for considering this is resource-based theory (Barney, 1991). Within this, knowledge is considered to be a (and perhaps the) critical resource (Wiklund \& Shepherd, 2003).

The notion of knowledge as a critical resource provides an insight into the role of international migrant entrepreneurs. There is a dynamic relationship between knowledge accumulation and entrepreneurship, and their co-evolution (Rae, 2004). While accumulated knowledge is essential to becoming an entrepreneur, entrepreneurship practices lead to further knowledge accumulation. Individual knowledge resources are the product of knowledge accumulation in a range of environments (Holt \& MacPherson, 2006, p.10). Human capital theories emphasise the importance of industry-specific experience and (Jo \& Lee, 1996), that is intrasectoral sources. But relevant codified, but especially tacit, knowledge can be accumulated in diverse sectors (inter-sectorally), or from working in particular external environments (extra-workplace), including a different country. This has particular implications for the type of knowledge transfer, as illustrated in Table 2. Intra-sectoral knowledge is likely to involve transfers of best or better practices between enterprises, for example, between two hotels. Inter-sectoral knowledge has two forms. Either knowledge transfers along the value chain, for example between tour companies and hotels, offering enhanced potential for co-production of innovations. Or, transfer of generalised knowledge of management practices and economic institutions, such as tax regimes. Finally extra-workplace knowledge is likely to involve hobby-related knowledge in the national context, and knowledge of everyday living and leisure in the international context.

Loane, Bell \& McNaughton (2007, p.490) assert that the innovative behaviour of key decision makers in internationalised firms ' $\ldots$ is often influenced by prior experience, in terms of international travel, being born abroad, having studied or worked overseas, access to global networks or foreign language capabilities'. Prior experience can provide networks, influence their orientation, and make them more cosmopolitan or open to new ideas (Williams, 2007a), and above all provides opportunities to acquire, what Bentley (1998) terms, 'uncommon knowledge'. Much of this knowledge is tacit, and some can only be transferred via co-presence, implying migration or mobility.

This can be illustrated by one particular form of uncommon knowledge, language capital (Dustmann, 2009). Liesch, Welch, Welch, McGaughhey, Petersen \& Lamb 
(2002, p.24) comment that '...for smaller firms, foreign language proficiency among staff may be an important factor in determining how internationalization is approached, including choice of country, and selection of agents or distributors'. Language capital allows access to a wider range of contacts and deeper understanding of markets. The latter requires a knowledge of culture and institutions, that is encultured or embedded knowledge (Blackler 2002) which may be language encoded; migrants - whether born abroad or having worked abroad - have the language skills to unlock such knowledge sources (Williams, 2007b). Potentially, they can enter a wider range of markets, or work with a wider range of partners compared to those who lack language capital. For example, some U.K. exporters recruit their overseas agents less on the basis of proven effectiveness than their English language abilities (Crick, 1999). The mediating effects of language capital are, of course, context specific. Firms innovating via internationalization, originating from countries with languages that have little international leverage, have to acquire knowledge of other languages, or rely on translation; the latter is necessarily limiting given that language usage is inherently cultural. In contrast, firms from English-speaking countries benefit from its status as a 'ground floor' global language (van der Heijden, 2002), although knowledge of a host country language still provides a deeper perspective on its culture and practices. There are, therefore, potentially important differences in how the sourcing of knowledge influences the internationalization of say small UK tour companies investing (and innovating) in Greece, depending on whether key personnel speak Greek.

Another important resource is material capital. Migrants usually have above average levels of education and skills (Borjas, 1987), but there is no particular reason to expect them to possess significant amounts of capital, compared to non migrants in host countries. One exception - although the numbers are small - is that several countries operate entrepreneur visa systems, for which there is usually a minimum capital requirement (McLaughlan \& Salt, 2002). In contrast, return migration is potentially a more important source of capital for entrepreneurial tourism ventures (Williams \& Hall, 2002). Returned ('unskilled') migrants in the period of mass migration in Europe had a high propensity to invest in small businesses, both for economic and social status reasons. As King (1986, p.21) comments on this period, on southern European countries in particular, 'going to Germany seems to convert peasants into petty traders'. Low entry barriers and life style aspirations attract many returnees to running small hotels, restaurants and bars (Mendonsa, 1982; Kenna, 1993). In recent decades, migrants - at least within Europe - have tended to be more temporary, and more skilled, with less evidence of return to tourism entrepreneurship. The extent to which such firms are innovative - other than in terms of imitative or replicative innovation - is therefore questionable.

In addition to the resource theory perspective, innovative behaviour in internationally owned/managed SMEs can also be analysed through the lens of the ethnic SME literature, although migrants only constitute one strand within this group. The classic model is Waldinger, Aldrich \& Ward's (1990) 'interactive approach' which situates ethnic enterprise at the confluence of complex interactions between opportunity structures (market conditions, access to ownership, and mediating government policy) and group characteristics (predispositions such as blocked mobility and aspirations; and resources mobilization, including ethnic networks and collaboration). 'Opportunities' are evident, for example, in the emergence of ethnic/migrant travel 
agents serving a related market segment, while - at a later stage - heritage tourism may develop around the history of migration (Williams \&, Hall, 2002, pp.20-21). There is also evidence of the importance of ethnic networks in some activities such as restaurants, although less so in respect of others, such as hotels. Nevertheless, these models provide a framework for questioning whether the distinctiveness of ethnic SMEs influences innovation: how do their resources (typically informal), ethnic submarkets, and co-ethnic business networks influence the sourcing or implementation of innovation? An additional twist is given to this perspective by considering transnational entrepreneurs (Portes \& Guarnitzo, 2001) who mobilize simultaneous connections to networks in two or more countries in search of markets, capital or supplies (Ruisinovic, 2008), which necessarily shapes innovation.

One of the key questions in relation to migrant and ethnic small firms is whether they can achieve 'break out' from what is often a localised and ethnic (migrant) market starting point for their business. This is explained in terms of a double axis by Ram \& Jones (1998) involving movement into non-ethnic and, or non-local market segments, in other words marketing innovation. Second generation migrants are especially innovative in this respect. Peters (2002), for example, shows how the second generation can exploit their positioning between two cultural social milieus and identities, whether in taking the family business in new directions, or building individual careers. Pécoud (2003) refers to this as hybridisation. In tourism, this can be illustrated by a hotel which starts by catering for a particular national market segment, but subsequently - and perhaps through a second generation migrant owner - undertakes marketing and product innovations to broaden its market.

\section{The internationalization of tourism labour markets}

Increased international migration has had implications for employment in a range of tourism environments, whether global cities such as London (Church \& Frost, 2004) or mass tourism destinations, such as the Balearics (Salvà-Tomas, 2002). This internationalization of labour has consequences for innovation through mediating both the supply of labour, and the role of employees in the co-creation of innovation; in other words, as a factor of production versus source of knowledge transfer.

In terms of factor of production, international migration contributes to the supply of, and potentially reduces the cost of, labour. Firms are concerned with effective unit production costs rather than nominal wage costs (Shaw \& Williams, 2004). Migrant workers tend to be paid lower wages than non migrants, and irregular migrants are especially vulnerable to exploitation (Matthews \& Ruhs, 2007) Given widespread perceptions amongst tourism employers that migrants are more flexible, more reliable and more committed than non migrants (Baum, 2007), they are seen as being cheaper in terms not only of nominal wages but also effective unit production costs.

International labour migration impacts on tourism innovation in three main ways. First, by lowering effective unit production costs, they change the relative costs of productions factors, especially of labour versus capital, discouraging investment in new technology. Secondly, if migrants have higher general levels of skills than nonmigrant workers, and if they are more adaptable to the introduction of new working practices, this increases the general absorptive capacity of the firm for innovation (Zahra \& George, 2002). In other words, international migration may remove some 
barriers to innovation.

Thirdly, international migration may introduce new or different skills into the workforce, perhaps because they are better educated and more numerate, or have acquired different competences from hospitality schools abroad. Human capital theory contends that international migrants have nationally specific human capital, which means that their productivity is initially lower than indigenous workers' (Chiswick \& Miller, 1995) because they lack sufficient knowledge of language, culture and institutions to utilise their other skills effectively (Williams, 2007a). However, this is not necessarily disadvantageous in tourism where many back-stage jobs involve little contact with customers, whether in kitchens, cleaning, or making beds, and only rudimentary language skills are required to perform mostly routine tasks. However, where migrant workers are fluent in the host country language, this can be a resource for firms. Given the internationalization of tourism demand, and the mobility of tourists, noted earlier, increasing numbers of tourists are seeking services in countries where they do not speak the language, and the cultural norms are, to some degree, unfamiliar (Williams, 2007a). Tourism firms may be willing to pay a premium for workers who possess appropriate language capital, as Aitken \& Hall (2000) record in New Zealand hotels that regularly host visitors from East Asia; this represents significant internationalization-related innovation in the process of service delivery.

A different perspective on migrant workers is their potential role as vehicles for knowledge transfer. Tacit knowledge is highly personalized and embedded in the individual (Polanyi, 1966). Therefore, migration is an effective, but highly selective, means of transferring tacit knowledge (Williams, 2007a), and a potentially important mechanism of knowledge overspills (Arrow, 1962). The question is whether their knowledge is different to that of indigenous workers. More specifically, does the crossing of borders (of all types) by knowledge-bearing individuals create opportunities for unusual learning (Wenger, 2000) and innovation, and are national borders significant in this respect? International human mobility does potentially result in the transfer of 'uncommon knowledge' (Munir, 2002), whether in the destination, or on return to countries of origin, so that migrants are potential knowledge brokers or boundary spanners (Wenger, 2000; Tushman \& Scanlan, 1981). International work experience is not necessarily more valuable than other forms of knowledge acquisition, but it is an important component of what we term 'blended knowledge': it is ' ... considered one of the most broadening elements of executives' backgrounds, since it typically complements and expands on the role played by other experiences' (Carpenter \& Fredrickson, 2001, p.535).

Knowledge transfer can be realized via intra-company transfers, mostly of managers and technical staff, based on an understanding that: 'The transfer of technology (especially when it implies a high degree of tacit knowledge) can easily fail if governed by a long-distance contract as it requires close and fluent liaison between those who transfer knowledge and those who receive it' (Rodriguez, 2002, p.603). MNEs, as noted earlier, therefore manage intra-company staff mobility in order to either distribute knowledge or collectivize it (to the organizational level) (Morgan, 2001). This feeds into internationalization-related innovation. As Carpenter \& Fredrickson (2001, p.535) comment: 'firms are most likely to have expansive global strategic postures when they are led by top managers who have the diverse network ties, skills, and worldviews that typically accompany demographic heterogeneity'. 
Implicitly this recognizes the importance of mobilising difference (Brown \& Duguid, 1991) as a source of innovation (Randel, 2003). There is little research on how this is articulated in tourism but Yang (2007) provides a case study of the role of hotel employees in knowledge transfer.

Significant international mobility is not limited to intra-firm transfers but also involves extra- or inter-firm mobility, and there is evidence that increasing numbers of migrants are free agent movers and learners (Opengart \& Short, 2002; Williams, 2006), pursuing boundary-less careers (Arthur \& Rousseau, 1996). They are all potentially sources of uncommon knowledge (Bentley, 1998). This is particularly relevant given there is evidence that labour turnover may be the most significant channel for knowledge spillovers, at least in MNEs (Glass \& Saggi, 2002).

The notion of free agent movers has particular resonance for the tourism industry, where the complexity of labour migration has been documented. Uriely (2001: 6), for example, conceptualises migrant workers in tourism in terms of the two axis of engagement in tourism, and the tourism orientation of their migration. This produces a fourfold classification:

- Travelling professional workers (TPW): mainly work related, engaging in tourism activities as a by-product of travelling;

- Migrant tourism worker $(M T W) s$ : travel for economic reasons, but only amongst tourism places given their pleasure orientation

- Non-institutionalised working tourists(NIWT): work while travelling to support their trip

- Working-holiday tourists (WHT): work is part of their tourism experience e.g. volunteer conservation workers

All four types of migrants potentially possess uncommon knowledge - whether to country or sector, or both - and could potentially contribute to innovation. Which type is more likely to influence innovation, depends on the relative importance attached to these two sources of knowledge transfer, and work orientation. In respect of the latter, the work-orientated types of migration are more likely to engage in co-learning, and to contribute to innovation (see Table 3).

Migrant workers may also have a distinctive role to play in the co-production of innovation, in context of the Service-Dominant Logic and an open innovation culture based on curiosity (Lafley \& Charan, 2008), as well as the recognition that human resources are the key to competitiveness in the service sector (Sirilli \& Evangelista, 1998). Probably the biggest barrier they face in terms of knowledge transfer is whether there is a culture of openness and co-learning amongst their fellow workers. Is diversity valued in tourism firms? The answer is inevitably highly contingent, but the question has barely been addressed.

In summary, tourism is characterized by relatively high levels of labour turnover because of relatively low entry barriers into tourism jobs: this is characterized as a situation of weak internal and strong external labour markets (Riley, Ladkin, and Szivas, 2002). Where migrant workers bring with them skills and experiences learned in other settings, this can be an effective channel of knowledge transfer. But, in practice, the casualization of the tourism labour supply, and the structural and sociopsychological features of the labour market (Riley, Ladkin and Szivas, 2002), suggest 
that knowledge transfers via labour mobility may be relatively less significant in tourism than in other sectors.

\section{Internationalization via consumption: the globalization of tourism}

The third key dimension of global connectivity relates to the role of international tourists via the globalization of demand and the changing nature of tourism consumption. Of particular importance is the internationalisation of tourism consumption and the increasing role that tourists play in the co-creation of innovations. Increased connectivity through the World Wide Web has enabled a collective of on-line collectives of tourist communities which can play critical roles in co-creating innovations.

International tourism has been expanding rapidly, outstripping domestic tourism in many countries (Knowles, Diamantis and El-Mourhabi, 2001), and becoming an important driver of the demand conditions that can be seen as either facilitating or driving tourism innovation. In other words, it can be analysed in context of demandled theories of innovation (Schmookler, 1976). Taking a step beyond this, internationalization of tourism demand also contributes to changing market segmentation, leading not only to growth in the level of demand but also the specificities of demand. The growth of international tourism may provide opportunities to innovate in terms of, for example, providing nationally-specific hospitality services, or foreign language guides at major tourism destinations.

In contrast, to this relatively passive role of international tourists in innovation, an alternative view sees them as contributing more actively as co-creators of innovation. This perspective, inevitably, takes us back to knowledge. Howells (2003, p.3-4) stresses that competences are constructed around consumption which require 'a whole set of attributes in investment, knowledge and enterprise in the consumption process'. This is associated with the notion of 'consumption knowledge' (Metcalfe, 2001, p.38), which repositions the consumer (tourist) as an active agent in innovation. That, in turn, links to the notion of the Service Dominant logic (Vargo \& Lusch, 2004) with the delivery of services increasingly being informed by the critical importance attached to consumers as co-creators of value. This has particular resonance for the tourism sector which has long been based around the customer experience, requiring close interaction between producers and consumers (Shaw, Bailey \& Williams, forthcoming 2010). In this framework, tourists are seen as operant rather than operand resources. The latter accords with the passive role of consumers noted above - as a market to be identified, analysed and targeted in marketing promotion campaigns. In contrast, customers as operants are a resource in the co-creation of tourism services. Not only is this particularly apposite to tourism but an important way of broadening our understanding of what constitutes resources in the resource theory of the firm.

Of course, the potential for co-creation applies to all consumers (tourists) and not only international ones. This can be seen in relation to the notion of the experience economy. Pine \& Gilmore (1998) emphasise that memorable experiences are particularly associated with the quality of the service delivery. There are two key aspects: consumer participation and the connection which links the customer to the experience event (Pine \& Gilmore, 1998). Tourists are 'dynamic social actors, interpreting and embodying experiences, whilst also creating meaning and new 
realities through their actions' (Selby, 2004, p.191). They interact with other tourists both within and outside their immediate group, with employees, and with local residents (as well as non-human actants), in a process of co-creation which necessarily means they are innovating in respect of the tourism experience. It is this process of innovation which gives meaning to particular tourism encounters.

The particular significance of international tourists in this context, other than as a significant, growing and sometimes the dominant market sector for some firms, lies in their distinctiveness. Despite some tendencies towards the globalization of tourism and leisure experiences, international tourists bring cultural values and accumulated experiences and knowledge, including language knowledge, to these encounters which are different to those of domestic tourists. There is therefore a compelling reason for firms to engage them as a distinct group of co-creators of innovation, although less compelling evidence that this is common practice in the industry. International tourists will have different experiences - amongst themselves as well as in relation to domestic tourists - while motivations, expectations and behaviour are all deeply culturally imbued. However, firms can learn not only about how to innovate in relation to this market segment, but also transfer ideas to supplying the domestic market.

Harvesting the knowledge of any group of tourists, let alone international tourists, poses challenges. As Poon (1993, p.272) argues: 'Their collective experience is a source of tremendous wealth'. In these terms, co-creation should be seen as colearning, and there have been major changes in the co-learning environment in recent years. Some of the most important relate to the web site developments, which range from those of individual firms, to search engines such as Tripadvisor, to individual blogs, all of which are forums for sharing travel experiences (Buhalis \& Laws, 2008). In many ways, and at least in terms of market information, rapid expansion of such sites has shifted power to consumers, although power relationships are inherently uneven within such web sites. However, these web sites represent more than information exchanges, for they also offer opportunities for tourists and producers to co-learn and innovate (Litvin, Goldsmithy \& Pan, 2008). Such activities also involve tourism firms in the process of open innovation where they commercially externalise pathways to the market by deploying outside resources (Chesbrough, 2003: for a recent contribution using travel trade examples see Brown et al. 2008)

The dominant but not exclusive language of such web sites is English, and this has become the modus operandi of global connectivity amongst international tourists and tourism firms. Access to such global connectivity is dependent on language capital: individuals need not only time and motivation, but appropriate language skills to contribute to these web sites - and the same applies to producers. Language, as always, becomes an instrument of power - power in this case for shaping innovation, via co-creation. Participation is also dependent on cultural values in relation to public versus private commentary, or acceptability of public criticisms of hosts. We still know very little about the way in which tourists are involved in the co-creation of innovation (Shaw, Bailey \& Williams, forthcoming 2010) and this is especially so for international tourists.

\section{CONCLUSIONS}


References to internationalization litter the tourism literature, and it is variously referred to as a driver, a shaper, or an outcome of change. However, relatively little attention has been given to either the conceptualization of internationalization in tourism, or to theoretically-informed empirical work that addresses two key questions: why, and how, do businesses internationalize their operations? This paper has explored how an innovation perspective can contribute to the challenge of deepening theoretical understanding in this area. Arguing that at the same time, a focus on internationalization will strengthen the emerging literature on tourism innovation. By way of conclusions, we set out six priorities as an agenda for taking this forward.

First, and expanding on the theme of internationalization being a form of innovation, there is a need to research how businesses approach this challenge. How do they understand internationalization as a form of innovation that drives their performance and competitiveness? And where does internationalization fit into the overall strategic plans of different types of firms - whether in terms of size, life-cycle, sub-sector or nationality? One of the keys to addressing this lies in the tensions between the logic of internationalization, in a globalizing economy, and the persistence of national and regional differences in consumption, and conditions of production. This echoes the call by Matsuitz (2010) for a better understanding of how 'glocalization', or the localization of globalization, is reshaping corporate strategies. Another way to approach this is by asking whether particular types of innovation, have distinctive international reaches - either in terms of potential, or even as a compelling driver. This was implicit in the OLI model as applied to hotels (Dunning and McQueen, 1982), but that can be fruitfully revisited through the lens of innovation research.

Second, if internationalization is understood as being dependent on successful innovation, this leads to the question of what constitutes the key innovations. No simple answer is likely to be forthcoming, not least because the focus of innovation shifts at different stages (Johanson and Vahlne, 1977) in the internationalization of tourism (Hjalager, 2007). What types of innovation are required in the initial, consolidating and mature stages? Can these be analysed through the traditional lenses of innovation typologies (Hall and Williams 2008), whether incremental versus discontinuous, or product versus process, organizational, marketing and institutional? Or is there a need for new typologies of innovation that specifically address the double specificities of tourism and internationalization? If so, these new typologies are likely to encompass how we conceptualize innovation in relation to mobile markets, localization versus standardisation, and complex organizational innovations in ownership, leasing and franchising.

Third, given that internationalization requires firms to have superior knowledge, we need to know what types of information are critical, and the determinants of effective knowledge transfer (Shaw and Williams, 2009). The existing research focuses mostly on MNEs, but the 'Born global' thesis (Knight and Cavusgil, 1996) emphasises, that small firms may also either be created as internationalized, or become so in the early stages of the life cycle of the firm. This can be approached in terms of the interplay between structural/institutional determinants and individual agency. The former takes us particularly to regulation (changes in minimum requirements, export assistance etc) and market shifts, while the latter takes us towards individuals and the positioning of individuals in networks, which determine the accumulation of knowledge, often in a highly erratic manner (Benito and Welch 1994). 
Fourth, given the evidence that tourism firms are relatively more reliant on external knowledge sourced from suppliers than on the internal creation of knowledge (e.g. via R\&D), Tourism firms do not simply buy in such innovates, but have to adapt them to their own needs, and this may involve varying amounts of co-production (Shaw et al 2010). Therefore, studies of internationalization need to examine how innovation may originate in international supply or value chains, and be distributed across space rather than be disseminated across space from a single point of origin (Véronneau and Roy, 2009). Such a perspective may take us to a more nuanced understanding of internationalization than is implied in the bipolarized debate about whether standardisation or localization takes centre stage in innovation. It is an approach which takes us away from seeing the national as the key site of production and innovation, to a greater recognition of globalization tendencies producing new and internationalised geographies of innovation.

Fifth, a focus on the individual firm, whatever its scale, will only take us so far given the transformational nature of the internationalization of flows in the economy (Castells, 1996). There is a need to analyse how firms are positioned in a shifting web of inter-related flows, which shape and reshape the conditions of production in terms human capital, entrepreneurship, and knowledge. It is not only firms whose relationships are being stretched across borders, but also individual managers and entrepreneurs, employees and tourists. There is a pressing need to better understand the global connectivities of tourism and tourism firms, requiring detailed and painstaking studies to map these out and to analyse how economic relationships are increasingly internationally constructed. Of course, the extent of such internationalization should not be exaggerated - and much if not most tourism activity remains resolutely national rather than international. But there is a need to think differently and more holistically about internationalization of both the firm and its external operating environment. This resonates with the notion of relational economic geographies (Yeung, 2005). Innovation shapes and is shaped by these interwoven relationships. This is especially evident in respect of knowledge flows articulated through the international mobilities of entrepreneurs and workers. What types of knowledge move with individuals, how are the generic and tourism components of this inter-related, and what facilitates and obstructs such flows.

Sixth, while - depending on definitions - the internationalization of tourism can be traced back not just centuries, but even millennia, this has intensified in recent decades, being evident in both the intensification and extensification of connectivities (Shaw and Williams, 2004, chapter two). To some extent tourists are moving along 'scapes' created by the investments of state and private capital, in combination with the routinized practices of tourists. In other words, the resulting geographies of internationalization are strongly path dependent (Bathelt \& Glückler, 2003). But tourists are also increasingly seen as active participants in the co-production of innovation, including tourism. Not least, individual tourists often act as pioneers signalling opportunities for tourism businesses. They are sources of knowledge, and there is a need to understand both how this differs from 'domestic' tourists and how businesses can harvest and apply this knowledge to innovation. At the same time, the simple bipolar construct of domestic versus international tourist needs to be deconstructed, because for many tourists these are increasingly interwoven and mutually informing learning experiences. 
Internationalization may no longer be the great adventure it once was for tourists, firms or their workers, but developing an understanding of the constitutive economic relations in this field remains a largely unfulfilled adventure for tourism researchers. 


\section{REFERENCES}

Aitken, C., \& Hall, C.M. (2000). Migrant and foreign skills and their relevance to the tourism industry, Tourism Geographies: an International Journal of Place, Space and the Environment, 2(3), 66-86.

Alexander , N., \& Dawson, J. (1994). Internationalisation of retailing operations. Journal of Marketing Management, 10 (4), 267-282

Amin, A. (2002). Spatialities of globalization. Environment and Planning A, 34: 385399

Amin, A., \& Cohendet, P. (2004). Architectures of knowledge: firms, capacities and communities. Oxford: Oxford University Press.

Arrow, K. J. (1962). Economic welfare and the allocation of resources for invention. In R. R. Nelson (Ed.), The rate and direction of inventive activity: Economic and social factors, vol. 13 (pp. 609-625). Princeton, New Jersey: NBER Special Conference Series, Princeton University Press.

Arthur, M. B., \& Rousseau, D. M. (1996). The boundaryless career: A new employment principle for a new organizational era. New York: Oxford University Press.

Barney, J. (1991). Firm resources and sustained competitive advantage. Journal of Management, 17, 99-120.

Bathelt, H. \& Glückler, J. (2003), Towards a relational economic geography', Journal of Economic Geography, 3 (2), 117-144

Baum, T. (2007). Human resources in tourism: still waiting for change. Tourism Management 28(6), 1383-1399.

Benito, G. R. G., \& Welch, L. S. (1994). Foreign market servicing: beyond choice of entry mode. Journal of International Marketing 2(2), 7-27.

Bentley, T. (1998). Learning beyond the classroom: Education for a changing world., London: Routledge.

Bianchi, R. (2002) Towards a new political economy of global tourism, in R. Sharpley and D. Telfer (Eds.), Tourism and Development: Concepts and Issues, (pp.265-299). Clevendon: Channel View.

Blackler, F. (2002). Knowledge, knowledge work and organizations, in C. W. Choo and N. Bontis (Eds.), The strategic management of intellectual capital and organizational knowledge (pp.47-62). New York: Oxford University Press.

Borjas, G. J. (1987), 'Self selection and the earnings of immigrants', American Economic Review 77(4): 531-553

Brown, J. S., \& Duguid, P. (1991). Organizational learning and communities-ofpractice: towards a unified view of working, learning and innovation. Organizational Science, 2(1), 40-57.

Buckley, P. J., \& Casson, M. C. (1985). The economic theory of multinational enterprise. London: Macmillan. 
Buhalis, D.' \& Laws, E. (2008). e Tourism case studies: Management and Marketing Issues, London: Butterworth-Heineman

Calof, J.L., \& Beamish, P. W. (1995).Adapting to foreign markets: Explaining internationalization. International Business Review 4 (2), 115-131.

Carpenter, M. A., \& Fredrickson, J. W. (2001). Top management teams, global strategic posture, and the moderating role of uncertainty. The Academy of Management Journal, 44(3), 533-545 .

Castells, M. (1996). The rise of the network society. Oxford: Blackwell.

Chesbrough, H.W. (2003) 'The Era of Open Innovation' MIT Sloan Management Review 44 (3), 35-41

Chiswick, B. R., \& Miller, P. W. (1995). The endogeneity between language and earnings: international analyses. Journal of Labor Economics, 13(2), 246-288.

Church, A., \& Frost, M. (2004). Tourism, the global city and the labour market in London. Tourism Geographies 6(2), 208-228.

Coe, N. M. \& Hess, M. (2005.) The internationalization of retailing: implications for supply network restricting in E. Asia and E. Europe. Journal of Economic Geography 5 (4), 449-473.

Cohen, E. (1972), Towards a sociology of international tourism', Social Research 39, 164-182

Coviello, N., \& Munro, H. (1997). Network relationships and the internationalisation process of small software firms. International Business Review 6(4), 361-386.

Crick, D. (1999). An investigation into SMEs' use of languages in their export operations. International Journal of Entrepreneurial Behaviour and Research 5 (1) 19-31.

Djankov, S., \& Hoekman, B. (2000). Foreign investment and productivity growth in Czech enterprises. World Bank Economic Review, 14, 49-64.

Dodgson, M., Gann, D., \& Salter A. (2008). The Management of Technological Innovation: Strategy and Practice. Oxford: Oxford UP.

Drejer, I. (2004). Identifying innovation in surveys of services: A Schumperian perspective. Research Policy, 33(3), 551-562.

Dunning, J. H., \& McQueen, M. (1982). The eclectic theory of the multinational enterprise and the international hotel industry. In A. M. Rugman (Ed.), New Theories of the Multinational Enterprise. London: Croom Helm.

Dustmann, C. (1999). Temporary migration, human capital, and language fluency of migrants. Scandinavian Journal of Economics 101(2), 297-314.

English -Lucek, J. A., Darrah, C. N., \& Saveri, A. (2002). Trusting strangers: work relationships in four high-tech communities. Information, Communication and Society 5(1), 90-108.

Etgar, M. (2008). A descriptive mode of the consumer co-production process. Journal of the Academy of Marketing Science 36, 97-108.

Fayed, H., \& Fletcher, J. (2002). Globalisation of economic activity issues for tourism. Tourism Economics 8(2), 207-230. 
Glass, A. J., \& Saggi, K. (2002). Multinational firms and technology transfer. Scandinavian Journal of Economics, 104(4), 495-513

Go, F. M., \& Pine, R. (1995). Globalization strategy in the hotel industry. London: Routledge.

Grant, R.M (1996). Toward a knowledge-based theory of the firm. Strategic Management Journal 17 (Winter Special Issue), 109-122.

Hall, C. M., \& Williams, A. M. (2008). Tourism and innovation. London: Routledge.

Hansen, M. T., Nohria, N., \& Tierney, T. (1999). What's your strategy for managing knowledge?, Harvard Business Review, March-April, 106-116.

Hitt, M. A., Bierman, L., Shimizu, K., \& Kochhar, R. (2001). Direct and moderating effects of human capital on strategy and performance in professional service firms: A resource-based perspective. Academy of Management Journal, 44(1), 13-28.

Hjalager, A.-M. (2007). Stages in the economic globalization of tourism. Annals of Tourism Research, 34 (2), 437-457.

Hjalager, A.-M. (2010). A review of innovation research in tourism. Tourism Management 31, 1-12.

Holt R., \& MacPherson A. (2006). Small firms, learning and growth: A systematic review and reconceptualisation, London: ESRC AIM.

Howells, J.R. (2003). Innovations, consumption and knowledge: services and encapsulation. Manchester: Centre for Research on Innovation and Competition, Discussion Paper 62.

Hymer, S.H. (1960). The international operations of national firms: A study of direct foreign investment, Cambridge, MA.: MIT Press (thesis 1960; published1976).

Jacob, M., \& Groizard, J. L. (2007). Technology transfer and multinationals: The case of Balearic hotel chains' investments in two developing economies. Tourism Management 28(4), 976-992.

Jo, H., \& Lee, J. (1996). The relationship between an entrepreneur's background and performance in a new venture. Technovation, 16(4), 161-171.

Johanson, J., \& Mattsson, L.-G. (1988). Internationalization in industrial systems - a network approach. In H. Hood \& J.-E. Vahlne (Eds.), Strategies in Global Competition (pp. 287-314). London: Croom Helm.

Johanson, J. and Vahlne, J.-E. (1977). The internationalization process of the firm - a model of knowledge development and increasing foreign market commitment.

Journal of International Business Studies, 8 (Spring/Summer), 23-32.

Johnson, C., and Vanetti, M. (2005). Locational strategies of international hotel chains. Annals of Tourism Research 32:1077-1099.

Jones M., \& Coviello N. E. (2005). Towards a unifying direction for international entrepreneurship research, Paper presented at Third McGill Biennale Conference. Toronto: McGill University.

Kenna, M.E. (1993). Return migrants and tourism development: an example from the Cyclades. Journal of Modern Greek Studies, 11(1), 75-95. 
Kindleberger, C.P. (1969). American business abroad, New Haven: Yale University Press.

King, R. (1986). Return migration and regional economic development: an overview. In R. King (ed.), Return Migration and Regional Economic Problems (pp. 1-37). Croom Helm, London.

Kleinert, J. (2004). The role of multinational enterprises in globalization. Berlin: Springer.

Knight, G. A., \& S.T. Cavusgil (1996). The born global firm: A challenge to traditional internationalization theory. Advances in International Marketing, 8, 11-26.

Knowles, T., Diamantis, D., \& El-Mourhabi, J. B. (2001). The globalization of tourism and hospitality: A strategic perspective., London: Continuum.

Kozinets, R. V., Hemetsberger, A. and Schau, H.J. (2008) 'Collective Innovation in the Age of Networked Marketing', Journal of Macromarketing, 28 (4), 339-354

Lafley, A. G., \& Charan, R. (2008). The game-changer: How you can drive revenue and profit growth with innovation. New York: Crown Books.

Lanfant, M.F., Allcock, J. B., \& Bruner, E. M. (eds) (1995). International tourism: identity and change. London: Sage.

Liesch, P. W., Welch, L. S., Welch, D., McGaughhey, S. L., Petersen B., \& Lamb, P. (2002). Evolving strands of research on firm internationalization: an AustralianNordic perspective. International Studies of Management and Organization, 32(1), 16-35.

Litvin, S. W., Goldsmithy, R.E, \& Pan, B (2008). Electronic word-of-mouth in hospitality and tourism management. Tourism Management 29 (3), 458-468.

Loane, S., Bell, J. D., \& McNaughton, R. (2007). A cross-national study on the impact of management teams on the rapid internationalization of small firms. Journal of World Business 42, 489-504.

McLaughlan, G., \& Salt, J. (2002). Migration policies toward highly skilled foreign workers, London, University College London: Migration Research Unit, Report to the Home Office.

Matthews, G., \& Ruhs, M. (2007). Are you being served? Employer demand for migrant labour in the UK's hospitality sector. Oxford, University of Oxford:

COMPAS Working Paper 51.

Matusitz, J. (2010). Disneyland Paris: a case analysis demonstrating how glocalization works. Journal of Strategic Marketing, 18 (3) 223 - 237.

Melin, L. (1992). Internationalization as a strategy process, Strategic Management Journal, 13 (Winter, 1992, special issue), 99-118

Mendonsa, E. (1982). Benefits of migration as a personal strategy in Nazaré, Portugal. International Migration Review, 16(3), 635-645.

Metcalfe, J.S. (2001). 'Consumption, preferences, and the evolutionary agenda', Journal of Evolutionary Economics, 11: 37-58.

Michel, S., Brown, S.W. and Gallan, A.S. (2008), 'Service-Logic Innovations: How to Innovate Customers, not Products', California Management Review 50 (3): 49-65 
Morgan, G. (2001). The multinational firm: organizing across institutional and national divides. In G. Morgan, P. H. Kristensen, \& R. Whitley (Eds.), The multinational firm: Organizing across institutional and national divides (pp.1-25). Oxford: Oxford UP.

Mungall, A., \& Johnson, C. (2004). Strategic and structural variables in internationalization: the case of Swiss tourism SMEs. In R. Thomas (Ed.) Small firms in tourism: International perspectives (pp278-296). Amsterdam: Elsevier.

NESTA (2008). UK global innovation: Engaging with new countries, regions and people. London: NESTA.

Nonaka, I., \& Takeuchi, H. (1995). The knowledge-creating company: How Japanese companies create the dynamics of innovation. New York: Oxford University Press.

Opengart, R., \& Short D C (2002). Free agent learners: the new career model and its impact on human resource development. International Journal of Lifelong Education 21(1), 220-233.

Paget, E., Dimanche, F., Mounet, J.-P. (2010). A tourism innovation case. An actornetwork approach. Annals of Tourism Research, 37 (3), 828-847.

Pécoud. A. (2003). Weltoffenheit schafft jobs: Turkish entrepreneurship and multiculturalism in Berlin. International Journal of Urban and Regional Research 26(3), 494-507.

Penrose, E. G. (1959). The theory of the growth of the firm. New York: Wiley.

Peters N. (2002). Mixed embeddedness: does it really explain immigrant enterprise in Western Australia ?. International Journal of Entrepreneurial Behaviour and Research 8(1/2), 32- 53.

Pine, J.B., \& Gilmore, J.H. (1999). The experience economy: Work is theatre and every business a stage. Boston: Harvard Business School Press.

Polanyi, M. (1966). The tacit dimension. London: Routledge \& Kegan Paul.

Poon, A. (1993). Tourism, technology, and competitive strategies. Wallingford: CAB International Books.

Portes, A., \& Guarnizo, L. E. (2001). Transnational entrepreneurs:The emergence and determinants of an alternative form of immigrant economic adaptation, Oxford, University of Oxford: ESRC Transnational Communities Centre Working Paper, WPTC-01-05.

Prashantham S. (2008). The internationalization of small firms: A strategic entrepreneurship perspective. Abingdon: Routledge.

Quinn, B., \& Doherty, A. (2000) Power and control in international franchising. evidence from theory and practice. International Marketing Review 17, pp.354-372.

Rae, D. (2004). Practical theories from entrepreneurs' stories: discursive approaches to entrepreneurial learning. Journal of Small Business and Enterprise Development, 11(2), 195-202.

Ram, M., \& Jones, T. (1998). Ethnic minorities in business, Milton Keynes: Small Business Research Trust. 
Randel, A. E. (2003). The salience of culture in multinational teams and its relation to team citizenship behavior. International Journal of Cross Cultural Management, 3(1), 27-44.

Riley, M., Ladkin, A., \& Szivas, E. (2002). Tourism employment: Analysis and planning. Clevedon: Channel View Publications.

Ritzer, G. and Liska, A., (1997) ' "Mcdonaldization" and "Post-tourism": complementary perspectives on contemporary tourism'. Pp. 96-109 in Rojek, C. and Urry, J. (eds), Touring Cultures: Transformations of Travel and Theory, London: Routledge.

Rodriguez, A. R. (2002). Determining factors in entry choice for international expansion. The case of the Spanish hotel industry. Tourism Management 23(6), 598607.

Rusinovic, K. (2008). Transnational embeddedness: Transnational activities and networks among first- and second-generation immigrant entrepreneurs in the Netherlands. Journal of Ethnic and Migration Studies, 34(3), 431- 451.

Salvà-Tomas, P. (2002). Foreign immigrants and tourism development in Spain's Balearic Islands. In C. M. Hall \& A. M. Williams (2002). Tourism and migration: new relationships between production and consumption (pp.119-134), Dordrecht: Kluwer.

Schmookler, J. (1976). Innovation and economic growth. Cambridge, MA: Harvard Univ. Press.

Schumpeter, J. A. (1934). The theory of economic development. Cambridge MA: Harvard University Press.

Selby, M. (2004). Consuming the city: Conceptualizing and researching urban tourist knowledge, Tourism Management 6(2), 186-207.

Shaw, G., Bailey, A., \& Williams, A. M. (forthcoming, 2010). Aspects of servicedominant logic and its implications for tourism management: Examples from the hotel industry. Tourism Management

Shaw, G., \& Williams, A. M. (2004). Tourism and tourism spaces. London: Sage.

Shaw, G., \& Williams, A. M. (2009). Knowledge transfer and management in tourism organisations: an emerging research agenda. Tourism Management_30(3), 325-335

Sinclair, M. T., \& Stabler, M. (1997). The economics of tourism, London: Routledge.

Sirilli, G., and Evangelista, R. (1998). Technological innovation in services and manufacturing: results from Italian surveys', Research Policy 27(9), 881-899

Smeral, E. (1998). The impact of globalization on small and medium enterprises: new challenges for tourism policies in European countries, Tourism Management, 19(4), 371-380.

Södersten, B., \& Reed, G. (1994). International economics, Third Edition, Basingstoke: Macmillan.

Sundbo, J. (1997). Management of innovation in services. Service Industries Journal 17(3), 432-455 
Uriely, N. (2001). 'Travelling workers' and 'working tourists': variations across the interaction between work and tourism', International Journal of Tourism Research 3, $1-8$.

Urry, J. (2000). Sociology Beyond Societies: Mobilities for the Twenty-First Century. London: Routledge.

Vargo, S. L., \& Lusch, R. F. (2004).Evolving to a new dominant logic for marketing. Journal of Marketing, 68(1), 1-17.

van der Heijden, B. I. M.. (2002), Individual career initiatives and their influence upon professional expertise development throughout the career. International Journal of Training and Development 6(2),: 54-79.

Vellas, F., \& Becherel, L. (1995). International tourism: an economic perspective, Basingstoke: Macmillan.

Vellas, F., \& Becherel, L. (1999). The international marketing of travel and tourism. London: Cassell.

Véronneau, S., \& Roy, J. (2009). Global service supply chains: An empirical study of current practices and challenges of a cruise line corporation. Tourism Management, 30 (1), 128-139.

Waldinger, R., Aldrich, H., \& Ward, R. (1990). Opportunities, group characteristics, and strategies. In R. Waldinger, H. Aldrich and R. Ward (Eds.), Ethnic entrepreneurs (pp.13-48). Newbury Park: Sage.

Welch, D. E., \& Welch, L. S. (1996). The internationalization process and networks: A strategic management perspective. Journal of International Marketing, 4(3), 11-28.

Wenger, E. (1998). Communities of practice: Learning, meaning, and identity, Cambridge: Cambridge University Press.

Whitla, P., Walters, G. P., \& Davies, H. (2000). Global strategies in the international hotel industry. International Journal of Hospitality Management, 26, 777-792

Wiklund, J., \& Shepherd, D. (2003). Knowledge-based resources, entrepreneurial orientation, and the performance of small and medium-sized businesses. Strategic Management Journal, 24(1), 1307-1314

Williams, A. M. (2006). Lost in translation? International migration, learning and knowledge. Progress in Human Geography 30(5), 588-607.

Williams, A. M. (2007a). International labour migration and tacit knowledge transactions: a multi-level perspective. Global Networks, 7(1), 1-22.

Williams, A. M. (2007b). Listen to me, learn with me: International migration and knowledge. British Journal of Industrial Relations 45(2), 361-382.

Williams, A. M., \& Hall C. M. (2002). Tourism, migration, circulation and mobility: the contingencies of time and place. In C. M. Hall \& A. M. Williams (Eds.), Tourism and migration: New relationships between production and consumption (pp.1-52). Dordrecht: Kluwer.

Williamson, O. E. (1973). Markets and hierarchies: some elementary considerations. American Economic Review, Papers and Proceedings 63(2), 316-325. 
Yang, J.-T. (2007). Knowledge sharing: Investigating appropriate leadership roles and collaborative culture. Tourism Management, 28, 530-543

Yeung, H. W.-c. (2005). Rethinking relational economic geography. Transactions of the Institute of British Geographers, 30: 37-51

Zahra, S. A. (2005). A theory of international new ventures: a decade of research. Journal of International Business Studies 36(1), 20-28

Zahra, A. Z., George, G. (2002). Absorptive capacity: A review, reconceptualization, and extension. Academy of Management Review, 27(2), 185-203 